University of Windsor

Scholarship at UWindsor

$1-1-1970$

\title{
The effect of gibberellic acid and the retardant AMO-1618 on the initial stages of growth and nucleic acid synthesis in etiolated soybean seedlings.
}

\author{
George Stanley Soteros \\ University of Windsor
}

Follow this and additional works at: https://scholar.uwindsor.ca/etd

\section{Recommended Citation}

Soteros, George Stanley, "The effect of gibberellic acid and the retardant AMO-1618 on the initial stages of growth and nucleic acid synthesis in etiolated soybean seedlings." (1970). Electronic Theses and Dissertations. 6874.

https://scholar.uwindsor.ca/etd/6874

This online database contains the full-text of PhD dissertations and Masters' theses of University of Windsor students from 1954 forward. These documents are made available for personal study and research purposes only, in accordance with the Canadian Copyright Act and the Creative Commons license-CC BY-NC-ND (Attribution, Non-Commercial, No Derivative Works). Under this license, works must always be attributed to the copyright holder (original author), cannot be used for any commercial purposes, and may not be altered. Any other use would require the permission of the copyright holder. Students may inquire about withdrawing their dissertation and/or thesis from this database. For additional inquiries, please contact the repository administrator via email (scholarship@uwindsor.ca) or by telephone at 519-253-3000ext. 3208. 
THE EEFE' OF GIBBERELLIC ACTD

AND T'HE RETARDAN'T AMO-1618

ON THE INITIAL STAGES OF

GROWTH AND NUCLEIC ACTD BYNTHESTS

IN ETTOLATED SOYBEAN SEEDLTNGS

$B Y$

GEORGE STANLEY SOTEROS

A THFSIS

Submitted to the Faculty of Graduate Studies

through the Department of Biology

in Partial Fulfillment of the

Requirements for the

Degree of Master of Science

at the University of Windsor

WTNDSOR, ONTARTO, CANADA

1970 
UMI Number: EC52836

\section{INFORMATION TO USERS}

The quality of this reproduction is dependent upon the quality of the copy submitted. Broken or indistinct print, colored or poor quality illustrations and photographs, print bleed-through, substandard margins, and improper alignment can adversely affect reproduction.

In the unlikely event that the author did not send a complete manuscript and there are missing pages, these will be noted. Also, if unauthorized copyright material had to be removed, a note will indicate the deletion.

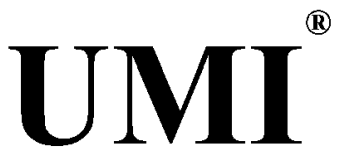

\section{UMI Microform EC52836}

Copyright 2008 by ProQuest LLC.

All rights reserved. This microform edition is protected against unauthorized copying under Title 17, United States Code.

ProQuest LLC

789 E. Eisenhower Parkway PO Box 1346

Ann Arbor, MI 48106-1346 
$A B L 4522$

Approved

324506

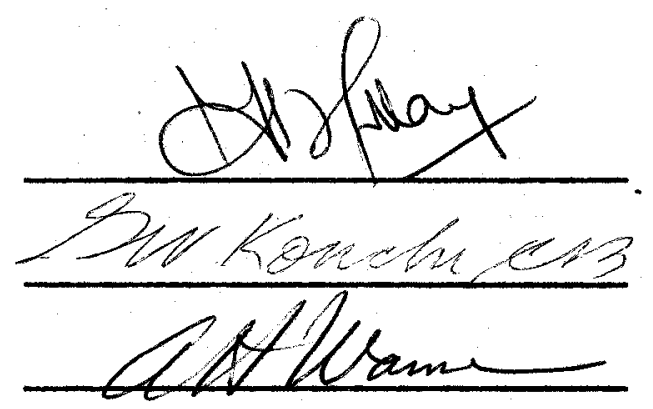

Reproduced with permission of the copyright owner. Further reproduction prohibited without permission. 


\section{ABSTRACT}

The plant growth retardant Allo-2618 is known to block the synthesis of glbberelins in various plant systems. The resulting retardation of the plant can sometimes be reversed In a kinetic manner by the application of gibberelin. In other systems, and/or at other concentrations, retardants have been shown to promote growth. It has been suggested that such retardant effects are not associated with sibberelin action but are a separate physiological effect. The present study demonstrates that such a promotive effect of AMO-1618 In roots and hypocotyls of etiolated soybean seedings may indeed be mediated by gibberelin application. Evidence is presented that this mediation involves changes in growth rates and in nucleic acid synthesis. The possible kinetics of this interaction are discussed. 


\section{ACKNOWLEDGEMENTS}

I wish to acknowledge my sincere thanks to Dr. D.T.N. Pillay, Department of Biology, University of Windsor, for his guidance and technical instruction during the course of my graduate education and the presentation of this thesis.

For critically reviewing this thesis, I wish to extend my sincere appreciation to Dr. G.W. Kosicki, Department of Chemistry, and Dr. A.H. Warner, Department of Biology, both of the University of Windsor. Special thanks are due to Dr. Warner and his co-workers for their patient assistance and interest.

I am very grateful for the help and encouragement freely given by Dr. W.G. Benedict, Dr. C.K. Sood, Mr. Y. Tu, Mr. G. Hou, Dr. P.N. Seth and especially Mr. C.F. Lynn.

I am indebted to the Windsor Board of Education for the sabbatical leave which enabled me to pursue these studies. I also wish to acknowledge financial assistance provided by Grant No. A-1984 to Dr. Pillay from the National Research Council of Canada. 


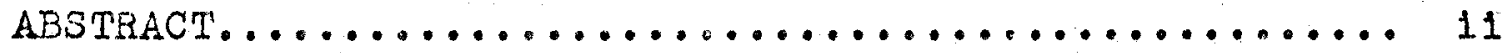

ACKNOWLEDGEMENTS....................... 111

TABLE OF CONTENTS....................... iv

LIST OF TABLES....................... v

LIST OF ILLUSTRATIONS.................... vi

ABBREVIATIONS.......................... vi1

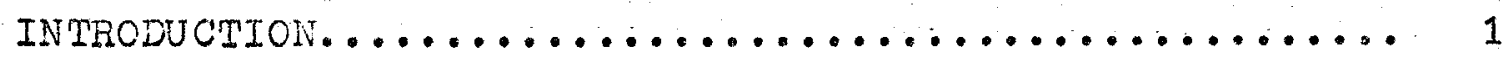

REVIEW OF IITERATURE.................... 2

MATERIALS AND NETHODS.................... 8

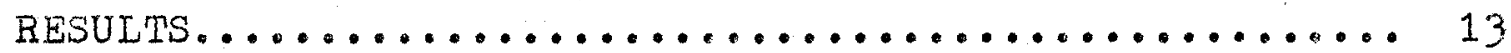

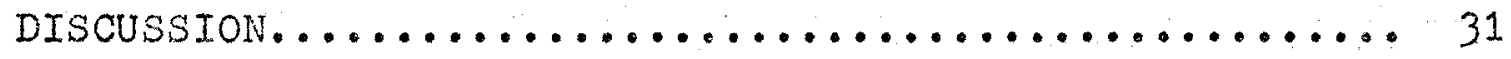

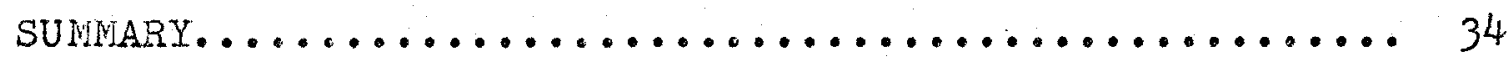

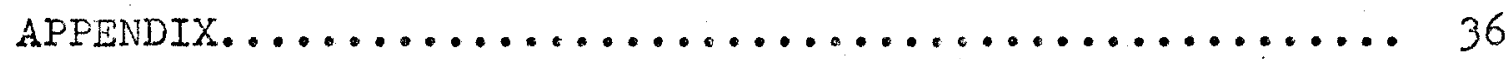

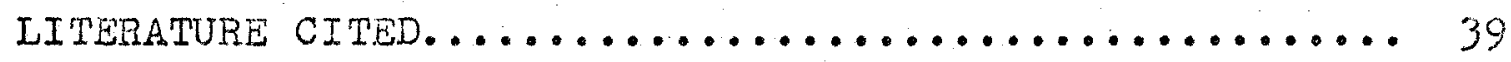

VITA AUCTORIS......................... 42 


\section{IIST OF TABLES}

Table

Page

1. Comparison of Cerenkov and scintillation

counting of $32 \mathrm{Fi}$ incorporated into nucleic

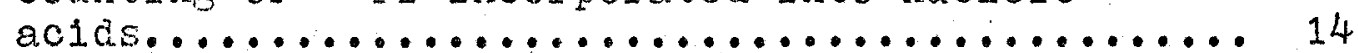

2. Distribution of 32 pj after incorporation

into nucle1c acids of water-grown soybear

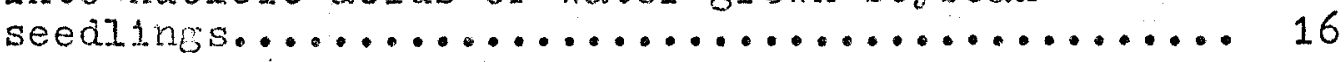

3. The onset of incorporation of $32 \mathrm{Fi}$ into

nucleic acid fractions from WAK chromatography... 18

4. The effect of high concentrations of AMO-1618

on the incorporation of $32 \mathrm{Pi}$ into nucleic acid

fractions of imbibing seeds............... 20

5. The effect of $G A$ and retarding Aro-1618 on incorporation of $32 \mathrm{pl}$ into nucleic acid

fractions of cotyledons.

6. The effect of $G A$ and $A M O-1618$ on the incorporation of $32 \mathrm{PI}$ into the nucleic acids of

soybean roots and hypocotyls............... 27 


\section{LIST OF ILLUSTRATIONS}

Figure

Page

1. Fractionation on MAK column of 6 day old

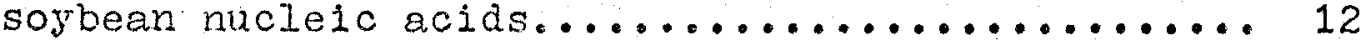

2. The eifect of GA and AMO-1618 on the growth of roots of 6 day old soybcan seedlings......... 24

3. The effect of GA and AMO-1618 on the growth of hypocotyls of 6 day old soybean seedings..... 25 


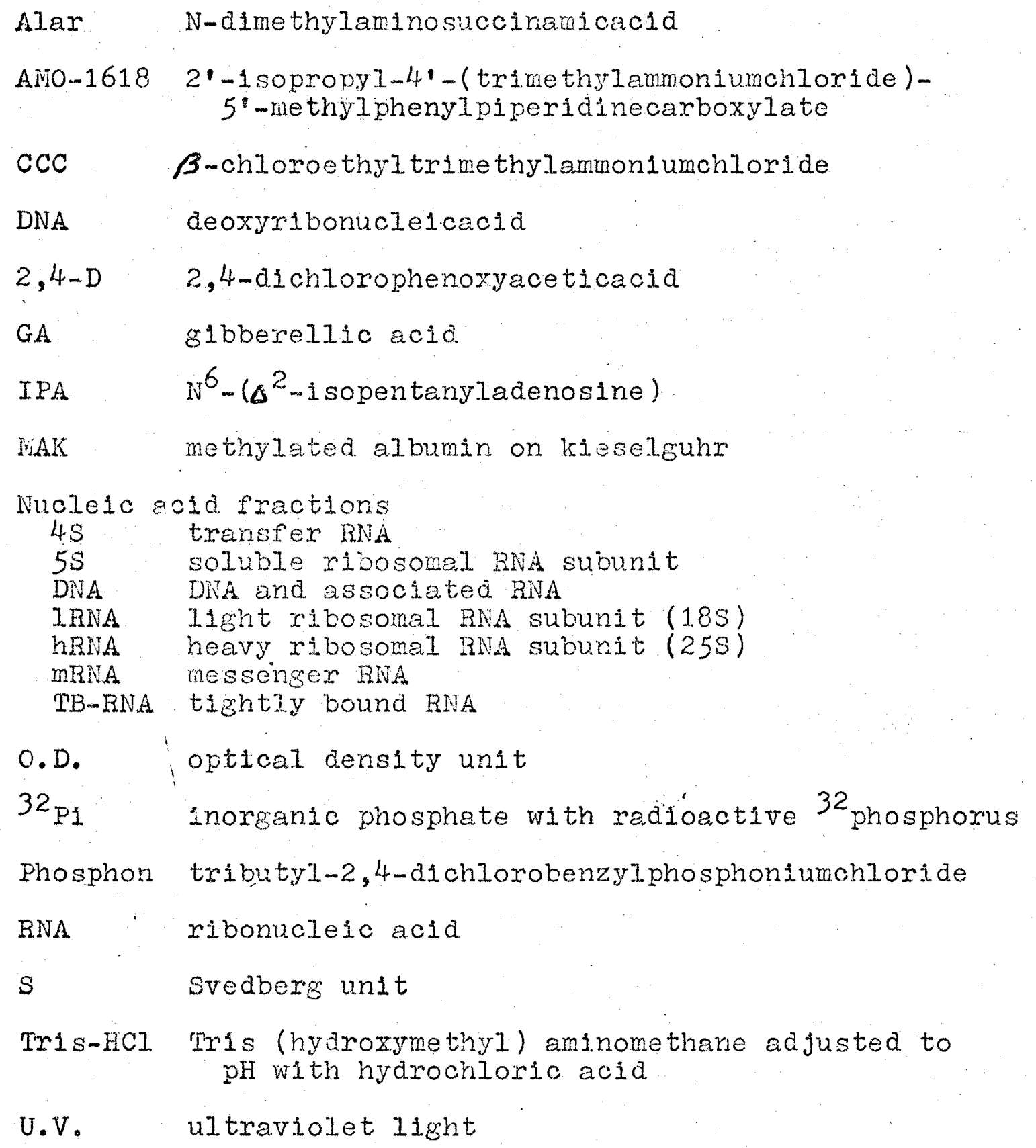

V11 


\section{INTRODUCTION}

Work in this and many other laboratories has attempted to correlate the actions of $\mathrm{AMO}-1618$ and $\mathrm{GA}$. Other work has been directed toward uncovering specific sites or modes of action of each of these chemicals. It now seems fairly clear that at least one of the actions of AMO-1618 is to block a specific step in the biosynthesis of GA. Thus AkO1618 should have demonstrable effects on any plant processes that require de novo production of GA for their completion and these effects should be completely reversed by externally supplied GA. Previous work in this laboratory (Yu Tu, 1970) showed that general changes in total cell wall, protein, and nucleic acid content of pea tissues simply reflect the overall growtin responses of the plant to these chemicals. Since their effects are broad it seems that the major action of GA is at the level of nucleic acid synthesis.

The purpose of this study was to determine the specific effects of these two chemicals at the level of nucleic acid metabolism in soybean seedings. Inttially it was necessary to establich reliable fractionation procedures for nuoledo acids using MAK columns. Finally, an attempt was made to demonstrate a kinetic interaction between the growith retardant AMO-1618 and the plant growth regulator GA with a special view to determining whether or not erowth responses to these chemicols are reflected in some or all nucleic acid fractions. Details of these two efforts are presented in tinis thesis. 


\section{REVIEW OF LITERATURE}

In the recent review of Glbberelins by Lane (1970) evidence was cited with respect to their distribution, biosynthesis, and mode of interaction with other plant hormones and some retardants. It appears that gibberelins are ubiquitous in distribution (Paleg, 1965; Lane, 1970; Tamura et al., 1969) and have multiple forms (Lang, 1970). Each different species appears to contain its own set of gibberellins and within a single species the kinds and quantities of the different gibberellins varies with organ and developmental stage.

Jones and Phill1ps (1966) have demonstrated that gibbereliins are synthesized in light-grown sunflowers, in the young leaves of the apical bud, and in the apical $(3-4 \mathrm{~mm})$ root tips. Developing seeds have also been shown to be sites of gibberellin synthesis (Kende and Lang, 1964). As a result, some mature seeds such as peas contain stores of gibberellins in a "bound" form (Bardense et al., 1968) making them independent of endogenous production for the first $2-3$ days of germination. The same group showed that Eharbitis seeds contain little stored hormone and require immediate synthesis of gibberelizins.

Dwarf and tall varieties of the same species are comon material used in attempts to elucidate the mode of action of gibberelin. Using dwarf and tall varieties of peas, Kende and Iang (1964) have shown that the act1vity of 
some glbberellins can be Inhibited by light while that of others cannot. They have also shown that etiolated dwarf peas, which grow tall, have a gibberelin level equal to that of light-grown dwarf peas, which are dwarfed. Radley (1970) has shown that, in IIght-grown wheat, GA stimulates the growth of tall cultivars but not the dwarfs (the reverse of the effect in peas), and in addition, that the dwarf. cultivars contain much higher GA levels than do tall cultivars. She suggested that in the dwarf there might be a "block to the utilization of GA caus( $1 \mathrm{ng}$ ) an accumulation of the hormone".

In 1970 Lang outlined the biogenesis of gibbereliins, as it is presently understood, from acetyl-CoA and mevalonate. It is interesting to note that two other plant hormones can be formed from intermediates in the same pathway; namely, the cytokinin IPA from isopentenyl pyrophosphate and absc1sic acid rom farnesyl pyrophosphate.

It is also clear that the retardants AMO-1618, CCC, and phosphon act as inhibitors of gibberelin synthesis by blocking the conversion of trans-geranylgeranyl pyrophosphate to copaly1 pyrophosphate (Dennis et al., 1965). As a result of this effect Iang (1970) was prompted to say that "these retardants can thus serve as a very useful tool in studying certaln questions of gibberellin physiology. They are a chemical knife that can do for us what the decapitation of the Avena colcoptile and other plants did in the study of auxin physiology". He cautioned that these retardants 
probably have other effects as well and that an interaction between GA and a retardant "can be related causaliy only if the effect on growth can be completely overcome by applied GA". As one example he cites evidence of CCC promoting growth in low concentrations possibly by becoming an additional source of reduced nitrogen for growth.

The retardant Aro-1618 which is used in this work was first reported by Wirwille and Mitchell (1950), and the interrelation between its molecular structure and function was characterized by Cathey (1965). Kende and Lang (1964) showed that Avo-1618 could dramatically inhibit the biosynthesis of gibberelin in developine pea seeds (by almost 30\%) at concentrations greater than $10^{-4} \mathrm{~N}$, while effectively reducing the growth of the seeds in fresh weight. However a lower concentration of approx. $10^{-5} \mathrm{~W}$ reduced endogenous GA levels by $60 \%$ without significantly affecting growth. They concluded that this result at the lower concentration "elimina(ted) the possibility that the changes in the gibberellin content of the seeds are the consequence rather than the cause of the changes in growth".

Halevy and Cathey studied the effect of gibberellins (1960a), of AMO-1618 (1960b), and of a combination of them in high concentration (Halevy, 1963) on the growth of cucumber seeding roots and hypocotyls. They found that the seedlings responded differently to the various gibberelins and that differing concentrations resulted in proinotive and retarding effects on both crgans. Their data concerning the 
effect of various concertrations of Ar:0-1618 shows that a concentration less than $10^{-5} \mathrm{~N}$ stimulates growth of darkgrown roots and hypocotyls while sreater concentrations progressively retard both. Halevy (1963) showed an inverse relationship between catalase and growth resulting from applications of GA and AMO-1618. A concentration of GA which stinulated hypocotyl growth but not radicle growth caused catalase levels to fall in hypocotyls but not in radicles. A concentration of AMO-1618 which inhibited both hypocotyl and root growth stimulated catalase in each. other retardants such as $\mathrm{CCC}$ and Alar were found not to affect catalase in this way.

Paleg (1965) has indicated that enhancement of the release of hycrolytic enzymes from aleurone layers of cereal grains by gibberellins was first demonstrated in work done independentiy by Yomo $(1958,1960)$ and Pales (1960). From subsequent evidence from other tissues he is led, in his review, to the conclusion "that the hormonal mechanisin results in a mode of action in which the synthesis of enzymically active protein occurs".

Much effort has been expended, therefore, in an attempt to find a mode of action of gibberelin and other hormones at the transcriptional and or translational level. For example, Johri and Varner (1968) have shown that "nucle1 isolated from shoots of light-grown peas in the presence of gibberellic acid $\left(10^{-8} \mathrm{M}\right)$ show a higher rate of DNA-dependent RNA synthesis than the untreated nuclei" and that this ENA is 
qualitatively different from the control. Fractionations on MAK columns showed the increased activity to be in the DNABNA and in the TB-RNA fractions. They suggest that "enhanced RNA synthesis could be due to increase in template sites on DNA and/or due to increase in the activity of the RNA polymerase enzyme itself".

since "the nuclei responded to the hormone only if they were isolated in its presence" they have suggested that "it is conceivable that some factor(s) present in the cytoplasm or nucleus is involved before GA elicits the rinal response. The fallure of purified nuclei to respond to hormone is perhaps related to the loss of this factor during isolation. Alternatively the hormone may in some way be involved in transporting a factor into the nucleus". Recently liatthyse and Phillips (1969) have shown that a protein mediator is involved in the auxin (2,4-D)-induced enhancement of DNA dependent RNA synthesis by isolated nuclei from tobacco or soybean tissue cultures or chromatin from pea buds. Yasuda and Yamada (1970) have recently shown thet $2,4-D$ complexes with histones during callus induction (dedifferentiation) in pea epicotyls.

On the other hand, Gayler and Glasziou (1969) have shown in sugar cane internodes that GA, at a high concentration $\left(5 \times 10^{-3} \mathrm{M}\right)$, has no effect on peroxidase nor does it affect invertase breakdown or synthesis, but 1t does "increase the enzyme forming capacity" for invertase. Thus, they suggest that GA and auxin (Irom other work in the same 
paper) may act by stablilzing specific mRNA species thereby increasing their "enzyme-forming capacity". It should be noted that Jonrl and Varner (1968) used a physiological concentration of glbberelin while Gayler and Glasziou used a very high concentration thus putting into question the physiological significance of their results. 


\section{Growth of Soybean Seedlings}

All experiments were conducted using soybeans, Glycine maximus L. var. Harrowsoy 63. The seeds were graciously supplied by the Research Station, Canadian Department of Agriculture, Harrow, Ontario. Seeds were surface sterilized for 20 minutes prior to use with javex-water $*(1: 16 \mathrm{~V} / \mathrm{v})$ and grown in the dark in high humidity for various periods of time up to 6 days. Youneer seedlings (up to 3 days old) were grown at $30^{\circ} \mathrm{C}$ in sterile plastic petri dishes containing initially $20 \mathrm{ml}$ of test solution or water as the control. At the end of every 24 hour pexiod, each dish of seeds was rinsed and supplied with $5 \mathrm{ml}$ of fresh solution. Older seedlings were either grown at $30^{\circ} \mathrm{C}$ in vermiculite in plastic trays or at $24^{\circ} \mathrm{C}$ between glass plates (single diamond, $20 x 20 \mathrm{~cm}$ ) and filter paper moistened with appropriate solutions. In this procedure surfece sterilized seeds were first imbibed in sterile petri dishes in the test solution overnight and seeds with a healthy appearance were set in a Iine $3 \mathrm{~cm}$ from the top of the glass plate under the moistened paper and supported in place by an elastic band which ensured that the paper and seeds remained in place when the plates were placed upright in a metal rack. The lowest $2 \mathrm{~cm}$ of eacl plate was enclosed in a small reservolr made from

"Javex contains $5.25 \% \mathrm{NaOCl}$ as the active agent. 
folded aluminum foll. The rack, with its several plates, was placed in a cardboard box, Ilned with saran wrap, and covered with aluminum foll to ensure darkness and a high humidity.

\section{Incubation of Tissue}

In each case the tissue was held in a solution containing $10^{-4} \mathrm{H}$ ammonium oitrate, $1 \%$ sucrose, and $50 \mu \mathrm{s} / \mathrm{ml}$ chloramphenicol with or without GA or ANO-1618, in varying concentrations and for appropriate times. Hypocotyls and roots were divided into approximate $2 \mathrm{~cm}$ sections while cotyledons were sliced into 3 sections along the long axis with a razor blade.

\section{Incorporation of 32 pi}

For 1sotope incorporation stuaies either 0.5 or 1.0 inC of $32 \mathrm{pi}$ (carrier free orthophosphate) was added to each flask usualiy containing $30 \mathrm{ml}$ of incubation mediun and tissue. The contents were continuously agitated in a water bath at $30^{\circ} \mathrm{C}$ for 2 or 3 hours, respectively. Incubation was halted by washing the tissue three times with ice-cold $0.05 \mathrm{~W}$ phosphate buffer ( $\mathrm{pH} 6.7)$ then ice-cold distilied water. The tissue was then Iyophilized in a freeze-drier for extraction of nucleic acids.

4. Extraction and Furification of Nuclejo Actas Extraction was done essentially by the Phenol-Tris buffer method employed by Cherry (1966). Samples were 
homogenized at $5^{\circ} \mathrm{C}$ in a solution containing $40 \mathrm{ml} 0.01 \mathrm{M}$ Tris-HCl (pH 7.6), $0.06 \mathrm{M} \mathrm{KCl}, 0.01 \mathrm{M} \mathrm{MO} \mathrm{Cl}_{2} ; 4.6 \mathrm{ml} \mathrm{1.1 \%}$ duponol; $65 \mathrm{ml}$ phenol (preequilibrated with the above Tris, $\mathrm{KCl}, \mathrm{MgCl}_{2}$ solution). All extractions were carrled out at $0^{\circ} \mathrm{C}$ or over 1ce. Homogenates were reextracted twice with phenol and bentonite. The aqueous supernatant was made $0.2 \mathrm{~N}$ with potassium acetate and the nucleic acids precipitated with 2 volumes of ethanol for at least 2 hours at $-10^{\circ} \mathrm{C}$. The precipitate was dissolved in $5-10 \mathrm{ml}$ of $0.05 \mathrm{M}$ sodium phosphate buffer ( $\mathrm{pH}$ 6.7) and dialyzed orernight against cold 0.05 m buffer.

\section{Chromatography on MAY Columns}

Purified nucleic acid extracts were fractionated on columns of Methylated Albumin or Kieselouhr essentially according to the method of Osawa and sibatani (1967). This method utilizes a three-layered column of cellulose powder, MAK, and kieselguhr instead of the original four-layered column of Mandell and Hershey (1960). (See Appendix). Typically, 35 O.D.'s of the partially purified plant nucleic acid were dissolved in $40 \mathrm{ml}$ of starting buffer, added to the column, and eluted with a linear gradient of $\mathrm{NaCl}$ from $0.3 \mathrm{~N}$ to $1.5 \mathrm{~W}$ in $0.05 \mathrm{~m}$ phosphate buffer ( $\mathrm{pH} 6.7$ ) using $250 \mathrm{ml}$ of each. Fractions containing 5-6 ml were collected and the ultra-violet absorbancy of each fraction was determined at $258 \mathrm{~m} \mu$ using either a Unicam Spectrophotomater (model $\mathrm{Sp} 800$ ) or a Beckman DB-G grating spectrophotometer. 
The dass columins used were designed and constructed in this laboratory from simple glass tubes of $2.5 \mathrm{~cm}$ ID and $24 \mathrm{~cm}$ length to a coarse sintered glass disc. The lower end was tapered to fit thin tubing which could be easily clamped.

\section{Scintiliation Counting}

Detection of $32^{2}$ i was tried using either

a) toluene, PPO, and POPOP

or b) toluene, PPO, POPOP, and methyl cellosolve (1.000 $\mathrm{ml}, 48,50 \mathrm{mg}$, and $700 \mathrm{mI}$, respectively) (Warrer and MClean, 1968)

or c) by detection of "Cerenkov radiation" directly from the aqueous solutions eluted from the column (Haviland and Bieber, 1970).

The Nuclear-Chicaso scintillation system (Nodel 6850) was used in all cases.

For the "Cerenkov" method $5 \mathrm{ml}$ of each fraction was mized with $5 \mathrm{ml}$ of distjlied water in glass scintillation vials and the radiation counted at the balance point.

Where specific activities of nucleic acid extracts and fractions from various treatments were compared the number of counts obtained for each calculation was corrected for decay. 
FIGURE 1

Fractionation on MAK Colum of 6 day old Soybean Nuclejc Acjas

A typical profije of a MAK fractionation of soybean rucleic acids using the simplified colum of Osawa and Sibatani. The nucleic acids for this example were extracted from 6 day old hypocotyls. peaks I to VI refer to 4S, 5S, DNA, IRNA, hRNA, and mRNA, respectively. The solid Iine is the U.V. profile while the dotted line represents the radioactivity. 


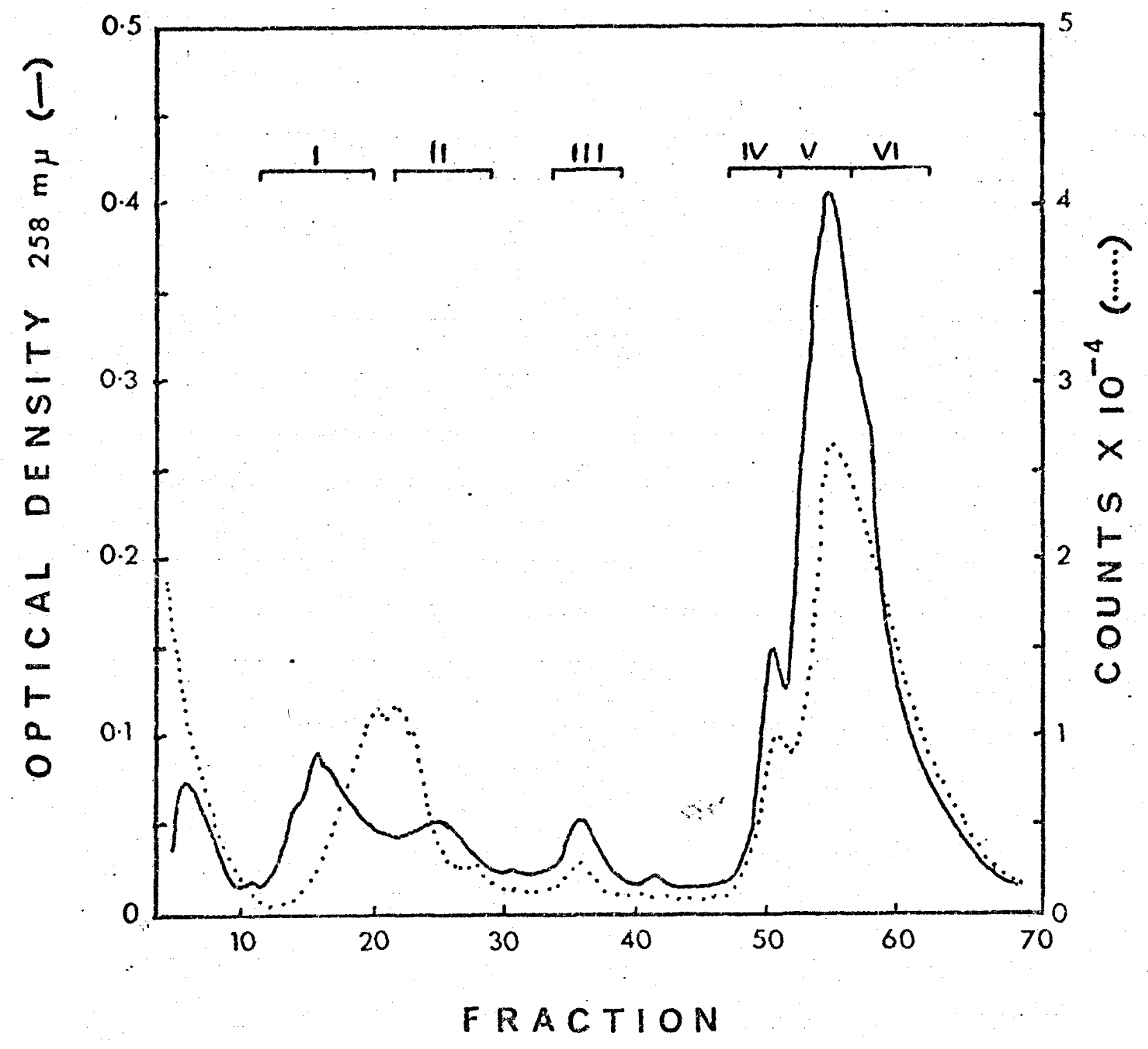

F1.g. 1. Fractionation on MAK Column of 6 day old Soybean Nucleic Aclds 


\section{RESULTS}

\section{Standardization of Procedures}

a) MAK column

The original procedures of Mandell and Hershey (1960) have undergone a wide variety of alterations at the hands of different workers. Attempts have been made to further elucidate the mode of action of the MAK in separating the various species of nucleic acid. It is still not clear exactly how the column effects the fractionation except that factors such as molecular size, hydrogen bonding content, and base composition seem to contribute to the separation. More recently Johri and Varner (1970) have implicated secondary structure in the separation of "mRNA" and TB-RNA.

Other workers have attempted to determine the limits of flexibility of the column. Attempts were made to utilize some of the simplified procedures in the fractionation of plant nucleic acids. The three-layered column of Osawa and Sibatani (1967) gives very reliable and repeatable fractionations whose $U$. $V_{0}$ and radioactivity profiles compare quite favourably with previous work using the classical Mandell and Hershey procedures (Fig 1 ). It was found, as have others, that the column could be safely reused, but in all the work reported here each column was used for only one fractionation. In addition 
TABLE 1

Comparison of Cerenkov and scintillation counting of $32 \mathrm{Pi}$ incorporated into nucleic acias.

\begin{tabular}{|c|c|c|c|}
\hline \multirow{2}{*}{$\begin{array}{l}\text { Counting } \\
\text { procedure }\end{array}$} & \multicolumn{3}{|c|}{ Counts $/ \mathrm{mLn} / \mathrm{ml}$ of nucle1c ac1d extract } \\
\hline & 1 & $\begin{array}{r}\text { Sample no. } \\
2\end{array}$ & 3 \\
\hline Scintillation & 37,870 & 15,370 & 5,940 \\
\hline Cerenizov & 7,310 & 3,110 & 970 \\
\hline $\begin{array}{l}\text { Cerenkov } \\
\text { as \% of } \\
\text { Scintillation }\end{array}$ & 19 & 20 & 16 \\
\hline
\end{tabular}

Aliquots $(0.1 \mathrm{ml})$ from each of 3 different nucleic acid fractions were counted as outlined in the Materials and Nethods for each counting procedure. 
it appears that storing the column for several days at $4^{\circ} \mathrm{C}$ has no effect on the operation of the column although the columns used in this work were stored in this way for no longer than three days. As well, the variation in glass column used seems to have had no ill effect on performance.

\section{b) Scintillation counting}

Haviland and Bieber (1970) have recently demonstrated that Cerenkov counting may well be "the method of choice for the detection of 32 pi". In this lab this method has not only given comparable and repeatable results but has the added advantages, as cited by Haviland and Bieber, of not requiring added scintillator as well as allowing the complete recovery of sample after counting. All. this, along with the maintenance of relative efficiency, certainly has made it the "method of choice" in this work.

Table $I$ shows a comparison of Cerenkov counting with that using scintillation flujd (Warner and $\mathrm{N}^{\mathrm{C}} \mathrm{Clean}, 1968$ ). $0.1 \mathrm{ml}$ of each of three different samples of radioactive nucleic acid extract was counted for one minute by each of the two methods. It can be seen that even at these low count levels the Cerenkov counting gave relative results quite comparable to the scintillation counting method. 
TABIE 2

Distribution of $32 p_{1}$ arter incorporation into nucleic acids of water-grown soybean seeds and seedings.

\begin{tabular}{|c|c|c|c|c|c|c|}
\hline \multirow{2}{*}{ organ } & \multirow{2}{*}{ ase } & \multicolumn{5}{|c|}{$\begin{array}{l}\text { Radioactivity as total counts/min } \times 10^{-3} \\
\text { ( } \% \text { of total added to column) }\end{array}$} \\
\hline & & $\begin{array}{l}\text { added to } \\
\text { column }\end{array}$ & $\begin{array}{l}\text { lost in } \\
\text { wash }\end{array}$ & $\begin{array}{l}\text { first } 10 \\
\text { tubes }\end{array}$ & $\begin{array}{l}\text { Wucleic } \\
\text { Acid }\end{array}$ & not \\
\hline seed & $12 \mathrm{hr}$ & 759 & - & $\begin{array}{l}141 \\
(19)\end{array}$ & $\begin{array}{l}6.2 \\
(0.82)\end{array}$ & $\begin{array}{l}612 \\
(81)\end{array}$ \\
\hline seed & $24 \mathrm{hr}$ & 689 & - & $\begin{array}{l}147 \\
(21)\end{array}$ & 8.3 & $\begin{array}{l}534 \\
(78)\end{array}$ \\
\hline seed & $48 \mathrm{hr}$ & 51 & - & $\begin{array}{l}18 \\
(35)\end{array}$ & $\begin{array}{l}1.8 \\
(3.5)\end{array}$ & $\frac{31}{(60)}$ \\
\hline $\begin{array}{l}\text { hypo- } \\
\text { cotyl }\end{array}$ & 6 days & 136 & $\begin{array}{l}45 \\
(33)\end{array}$ & $\begin{array}{l}18 \\
(13)\end{array}$ & $\begin{array}{l}34 \\
(25)\end{array}$ & $\begin{array}{l}38 \\
(28)\end{array}$ \\
\hline root & 6 days & 976 & $\begin{array}{l}103 \\
(11)\end{array}$ & $\begin{array}{r}40^{c} \\
(4)\end{array}$ & $\begin{array}{l}59 / 4 \\
(61)\end{array}$ & $\begin{array}{l}239 \\
(24)\end{array}$ \\
\hline
\end{tabular}

ascintiliation counting

${ }^{b}$ Cerenkor counting

Estimated from incomplete data

Incorporation, extraction, and MAK chromatography vere performed as outinned in the Materials and Methods. Are refers to time after first app,ication of distilied water which was used throughout. 
II The Interaction of GA and AMO- 1618

a) Initiation of Incorporation of 32 Ei into Nucleic Ac1d Fractions and Distribution of Badioactivity

In order to estimate the onset of a level of nucleic acid synthesis by imbibing seeds, surface sterilized seeds were placea in sterile petri dishes in the dark at $30^{\circ} \mathrm{C}$ and allowed to imbibe water for 12,24 , and 48 hours before incubation with $1.0 \mathrm{mc}{ }^{32} \mathrm{pi}$ for 2 hours. Table 2 shows the general distribution of radioactivity after elution through the column. Clearly the molecules into which the ${ }^{32} p_{1}$ are first incorporated consist majnly of those species which either remain bound to the column after elution or axe lost in the column wash during loading of the column. Obvious incorporation into nucleic acid fractions occurs sometime between 24 and 48 hours after imbibition starts (acceptable profiles have been achieved after 36 hours of imbibition). At this stage not only has incorporation occurred into all the nucleic acid fractions but an increase in incorporation into those molecules which elute first from the colum has also occurred. This is all at the expense of the molecules which either remain bound to the column after elution or are lost in the pre-wash. Table 2 also shows the distribution of radioactivity incorporated into fully growing organs. For 6 day old hypocotyls the radioactivity lost in the pre-wash plus that left bound to the column equal $61 \%$ of the total added to the colum (siniler to the 48 hour seed). On the other 
TABLE 3

The onset of incorporation of 32 E1 into nucleic acid fractions from MAK chromatography.

\begin{tabular}{crrrrrrr}
\multirow{2}{*}{$\begin{array}{c}\text { Water } \\
\text { (hr) }\end{array}$} & \multicolumn{5}{c}{ Specific activity (cts/OD, $258 \mathrm{mu})$} \\
\cline { 2 - 7 } & $4 S$ & $5 S$ & DNA & 1RNA & hRNA & mRNA $\begin{array}{l}\text { average, } \\
\text { all peaks }\end{array}$ \\
\hline 4 & 120 & 150 & 120 & 35 & 22 & 71 & 86 \\
12 & 120 & 93 & 110 & 36 & 23 & 37 & 70 \\
24 & 150 & 190 & 64 & 35 & 21 & 51 & 85 \\
48 & 3400 & 4300 & 2700 & 1700 & 840 & 900 & 2300 \\
\hline
\end{tabular}

Incorporation, extraction, and MAK chromatography were performed as outlined in the Materials and vethods. Age refers to time after first application of distilled water which was used throughout. 
hand, incorporation into moleic acids has greatly increased, compared to 48 hour seeds, almost totally at the expense of the activity that had eluted in the first ten, preprofile tubes.

Roots show a great increase in incorporation into nucleic acids predominantly at the expense of the precursors in the wash. In general it appears that the radioactivity. bound to the column after elution remains as a uniform percentage ô total incorporation and any increase in incorporation into nucleic acids seems to arise out of utilization of "precursors" that may comprise a great part of the activity eluted before the profile. Much work has been expended by various workers in attempting to eluoidate the nature of the M-RNA Ieft on the column. It would seem from the data presented here that an investigation of the radioactive compounds that elute prior to the nucleic acid profile might be quite useful.

Table 3 shows that the average specific activity of peak tubes of nucleic acids extracted from seeds up to one day old is foirly uniform and that they are only $3.5 \%$ as active in incorporation of ${ }^{32}$ pi as are two day old seeds. This low level of incorporation at early imbibition stages could either represent a minimal level of nucleic acid synthesis occurring in the seeds or could represent that level of activity contributed by contaninating organisms not inhibited by the chloramphenicol. In the incubation mediun. If the latter is the case it is inportant to re- 
TABLE 4

The effect of high concentrations of AMO-1618 on the incorporation of $32 \mathrm{Pi}$ into nucleic acid fractions of imbibing seeds.

\begin{tabular}{|c|c|c|c|c|c|c|c|}
\hline \multirow{2}{*}{$A M O-1618$} & \multicolumn{7}{|c|}{ Specific activity as $\%$ or control } \\
\hline & $4 S$ & 58 & DNA & IRNA & hRNA & MRNA & Ave. \\
\hline $3 \times 10^{-4} M$ & 77 & 92 & 92 & 85 & 93 & 96 & 88 \\
\hline $3 \times 10-4 \mathrm{~W}$ & 35 & 21 & - & 15 & 6.5 & 7.9 & 19 \\
\hline
\end{tabular}

Seeds were imbibed for two days in either distilled water or the appropriate AlO-1618 solution before $32 \mathrm{Pi}$ incorporation. AlI procedures were done as outlined in Materials and Methods. 
cognize that the contribution of contaminating oreanisms to the specific activity of 32 pi incorporation into nucleic acid fractions is no greater than $3.5 \%$ of the total.

b) The Effect of High Concentrations of AMO-1618 on the Incoryoretion of 32 pi into the Nucleic Acids of Imbibing Seeds.

A concentration of $3 \times 10^{-3}$ IS AMO-16.18 is lethal to imbibing seeds and allows only limited growth of the root when grom for more thon 48 hours. Table 4 shows that this erfect is reflected in a much reduced incorporation of 32 i into all fractions of nucleic acids. It is especially interesting, elven the importance of DNA in the production of RNA, that the incorporation into the DNA-RNA is reduced to background levels.

On the other hand $\mathrm{AMO}-1618$ at $3 \times 10^{-4} \mathrm{M}$ retards the development of both roots and hypocotyls but is not lethal. to the seedings. This is also reflected in an average $11 \%$ reduction in specific activity.

\section{c) The Effect of GA and ANO-1618 on Cotyledon Nucle ic} Acids.

Since cotyledons perform mainly a storace function and exhibit ifttle or no cell division in their development it was felt that they would represent a tissue which would offer the least number of physiological variables and thus would be the most appropriate tissue with which to compare the activities of these compounds. Variables were further 
TABLE 5

The effect of $G A$ and retardine $A$ AlO--1618 on incorporation of $32_{\mathrm{P} i}$ into nucleic acid fractions of cotyledons.

\begin{tabular}{|c|c|c|c|c|c|c|c|}
\hline \multirow{2}{*}{ Pretreatment ${ }^{a}$} & \multicolumn{4}{|c|}{ Specific activity } & \multicolumn{3}{|c|}{ cts/OD $258 \mathrm{mu}$} \\
\hline & 4.5 & $5 \mathrm{~s}$ & DNA & IRNA & hRNA & mPNA & $A V E^{b}$ \\
\hline AMO $12 \mathrm{hr} 30^{\circ} \mathrm{C}$ & 2220 & 3960 & 9470 & 1110 & $1330^{\circ}$ & 1320 & 3310 \\
\hline AMO $12 \mathrm{hr} 25^{\circ} \mathrm{C}$ & - & -- & 1060 & 350 & 450 & 640 & 550 \\
\hline $\mathrm{GA} \quad 12 \mathrm{hr} 25^{\circ} \mathrm{C}$ & - & -- & 1250 & 550 & 630 & 1030 & 860 \\
\hline 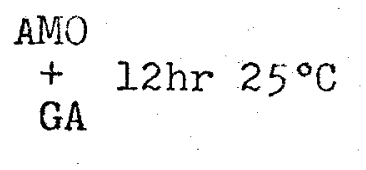 & 1230 & 1130 & 1190 & 460 & 640 & 1050 & 830 \\
\hline AMO I hr $25^{\circ} \mathrm{C}$ & 770 & 2060 & 1700 & 580 & 650 & 860 & 950 \\
\hline $\mathrm{GA} 1 \mathrm{hr} 25^{\circ} \mathrm{C}$ & 2410 & 3010 & 4990 & 820 & 1010 & 1280 & 2020 \\
\hline$\stackrel{+\mathrm{AMO}}{+} \mathrm{IA} \mathrm{hr} 25^{\circ} \mathrm{C}$ & 1580 & 2.140 & 2830 & 530 & 660 & 760 & 1200 \\
\hline
\end{tabular}

a all concentrations $=3 \times 10^{-4}$.

baverage of last 4 peaks only.

Cotyledons from six day old watermgrown soybean seedlings were pretreated as indicated before 32 pi incorporation and subsequent extraction and MAI fractionation as described in the riaterials and Miethods. 
reduced by the use of dark-brom cotyledons thus minimizing, in adition, chloroplast activity.

Table 5 shows the effects of sub-lethal $\left(3 \times 10^{-4} \mathrm{M}\right)$

doses of AMO-16I8 either separate from GA or in combination with it, on the incorporation of $32_{p 1}$ into the nucleic acid fractions of 6 day old, water-Erown cotyledons. It can be seen from the average specific activity that incorporation Into GA treated cotyledons is always the ereatest and into AMO-1618 the least with the combination of AMO-1618 and G.A (equimolar) having an intermediate activity. It is significant as well, that the responses are different with short and Iong pretreatment. GA caused 50-100\% greater $32 \mathrm{P} 1$ incorporation in both 1 and 12 hour pretreatments than did. ANO-1618 wille the mixture of AMO-1618 and GA acted Ijke AMo-1618 in the first houx but i1ke GA after 12 hours. Does this imply that AMO-1618 acts quickly, and that GA is able to overcome its affect on nucleic acid fractions only after a time? It must be remembered that this is the response of this tissue to these chemicals in concentrations at which each separately is retarding to the plant.

d) The Effect of GA and AMO-1618 on the Growth of Soybean seedings

Gibbereljic acid (GA) is generally known as a stimulator of plant growth while AMO-1618 is known as a retardant. In some plants GA can be shown to overcome the action of AMO-1618 in a competative way but in others the Interrelationship is not as clear. It is important, ther, 


\section{FIGURE 2}

The Effect of GA and AMO-1618 on the Growth of Roots of 6 day old Soybean seedlings

and

\section{FIGURE 3}

The Effect of GA and AMO-1618 on the Growth of Hypocotyis of 6 day old soybean seedings

Soybean seedings were grown for 6 days on glass plates as outlined in the Materials and Wethods in various concentrations of $\mathrm{All} O-1618$ and $\mathrm{GA}$ separately or in combination. Ten of the most typical seedlings from each treatment were selected and the average length of their roots and rypocotyls was determined.

$(\ldots)$
$(\ldots M O-1618$
$(\ldots \ldots)$
GA
$(\ldots-5 \mathrm{M}$ AMO-1618 + varying concentrations of $\mathrm{GA}$
$10^{-4} \mathrm{M}$ AMO-1618 + varying concentrations of $\mathrm{GA}$ 


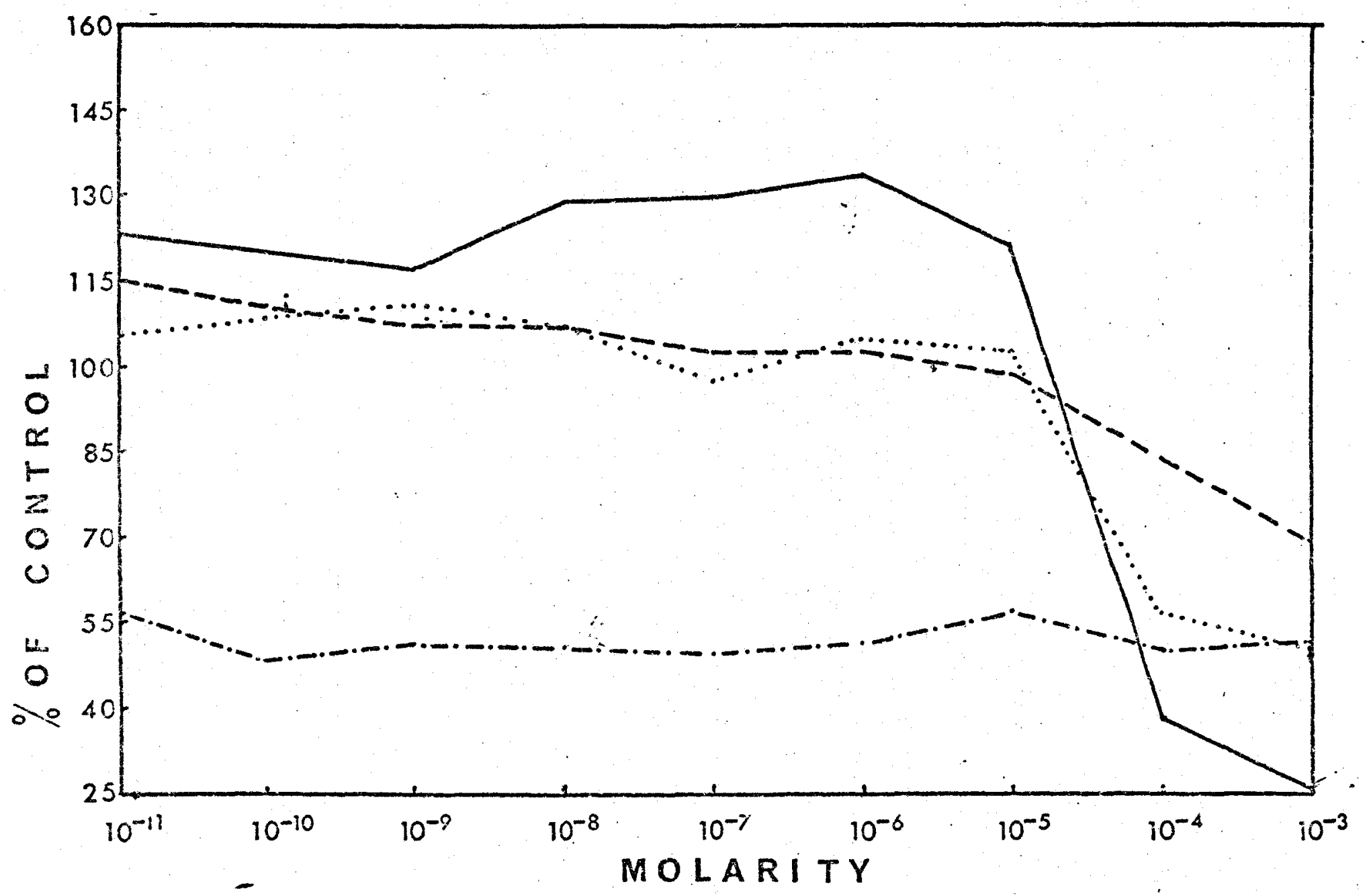

F18. 2. The Iffect of GA and ANO-1618 on the Growth of Roots 


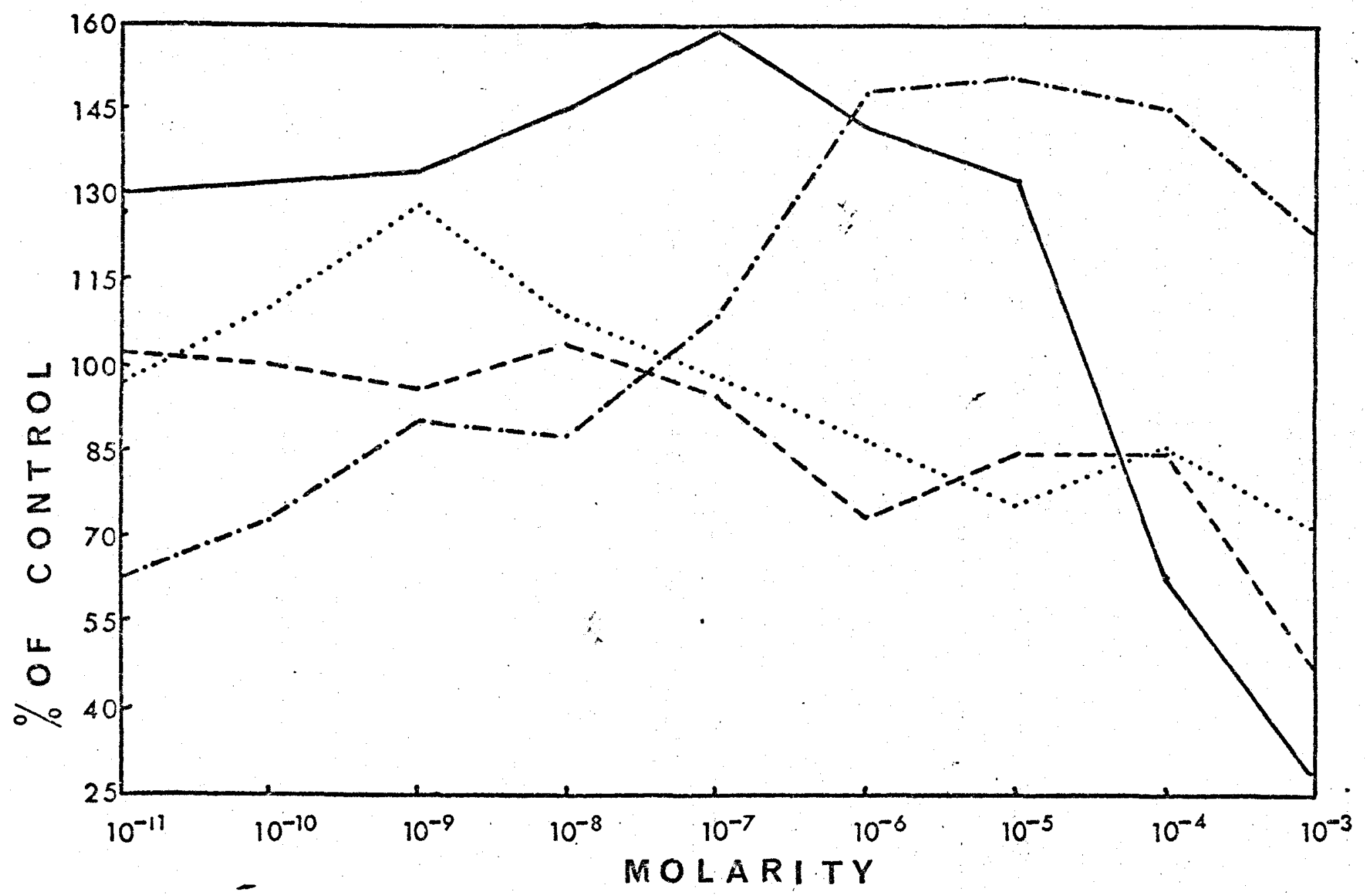

F18. 3. The Effect of GA and AMO-1618 on the Growth of Hypocotyls of 6 day old Soybean seedings 
to determine the mode of Intexaction between these two chemicals on the overall growth of the Harosoy 63 varlety of soybeans chosen for this work.

The results of a typical experiment are shown in Fig. 2 and Fig. 3 in which surface sterilized seeds were grown in the dark for 6 days between glass plates and filter paper soaked with the appropriate concentrations of test solutions. For roots it can be seen that GA is only slightly stimulatory to growth up to a concentration of $10^{-5}$ above which it begins to inhibit growth. AMO-1618, on the other hand, is much more effective in stimulating grovth, again up to a concentration of $10^{-5} \mathrm{M}$ above which it becomes much nore retarding than GA. GA appears to be able to completely overcome the promotive effects of AMO-1618 at $10^{-5} \mathrm{M}$ but it is unable to overcome the retarding effects of Aro-1618 at $10^{-4}$ H. It appears, then, that there is a direct relationship in soybean roots between $G A$ and AMO-1618, when AMO-1618 is used in a promotive concentration but not when AMO-1618 is in a retarding concentration.

Dor hypocotyls the interaction seers somewhat more complicated. Fror roots, the "critical concentration" at which pronction turns into retardation was the same for both GA and ARO-1618; namely, between $10^{-5} \mathrm{H}$ and $10^{-4} \mathrm{~m}$. But for hypocotyls this "critical concentration" is different for $G A$ being between $10^{-8} \mathrm{M}$ and $10^{-7} \mathrm{M}$. . This concentration appears to be significant as well in the 1nteraction of AlNO1618 and GA since at lower concentrations than this of GA a 


\section{TABLE 6}

The effect of GA and ANO-1618 on the incorporation of 32 Pi into the nucleic acids of soybean roots and hypocotyls.

$\%$ of control.

Specir1c Activity

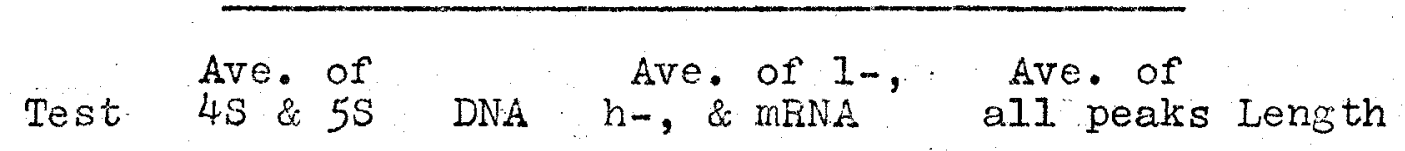

Roots

$\begin{array}{rrrrrr}\text { GA } 10^{-6} 6_{\mathrm{M}} & 9 & 16 & 33 & 19 & 103 \\ \text { GA } 10^{-3} \mathrm{M} & 19 & 5 & 22 & 15 & 70 \\ \text { ANO } 10^{-7} \mathrm{M} & 177 & 28 & 82 & 96 & 130 \\ \text { AMO } 10^{-4} \mathrm{M} & 192 & 68 & 140 & 133 & 37 \\ \text { GA } 10^{-8} 8_{\mathrm{MI}} & & & & & \\ \text { AMO } 10^{-4} & 45 & 20 & 70 & 45 & 51 \\ \text { GA } 10^{-4 \mathrm{M}} & & & & & \\ \text { AMO } 10^{-4} \mathrm{M} & 46 & 10 & 24 & 2 ? & 51\end{array}$

Hypocotyls

\begin{tabular}{|c|c|c|c|c|c|}
\hline GA $10^{-6} \sigma_{M}$ & 205 & 262 & 295 & 254 & 74 \\
\hline GA $10^{-3} 3_{\text {in }}$ & 35 & 54 & 59 & 50 & 48 \\
\hline AMO $10^{-7}$ in & 261 & 317 & 395 & 324 & 159 \\
\hline AMO $10^{-4}$ & 42 & 83 & 44 & 56 & 64 \\
\hline $\begin{aligned} \text { GA } & 10^{-8}-8 \\
\text { AMO } & 10^{-4}\end{aligned}$ & 69 & 68 & 83 & 73 & 88 \\
\hline $\begin{aligned} \text { GA } & 10^{-4} \\
\text { AMO } & 10^{-4}\end{aligned}$ & 267 & 226 & 336 & 243 & 145 \\
\hline
\end{tabular}

The roots and hypocotyls were harvested from the seedlings used in the growti experiment (section II (d) of these results). All procedures were as outlined in Materials and Methods. The $\%$ of control lengths are from the growth experiment. 
promotive concentration of AMO-1618 $\left(10^{-5}\right.$ in) has control while at higher GA concentrations the GA seems to have control.

The interaction of GA with a retarding concentration of AMO-1618 $\left(10^{-4} \mathrm{M}\right)$ is quite different except that the critical GA concentration 1 s again between $10^{-8} \mathrm{M}$ and $10^{-7} \mathrm{M}$. Increasing concentrations of $\mathrm{GA}$ from $10^{-11} \mathrm{~W}$ to $10^{-7} \mathrm{M}$ seem to progressively overcome the retarding effect of AMO1618 at $10^{-4} \mathrm{~W}$; but at higher concentrations of GA rather than the GA maintaining control the GA and AMo-1618 seem to act synergistically, promoting growth considerably where each separately would retard growth. It is quite clear then, though not surprisine, that the mode or interaction between these two chemicals is somewhat different in the two actively growing parts of the seedlings: the roots and the hypocotyls.

e) The Effect of GA and ANO-1618 on the Incorporation of 32 If into the Nucleic Acjds of the Growing Parts of Soybean seedings

Table 6 shows the results of a number of MAK column fractionations of the nucleic acids of seedlings harvested from the above plent growth experiments. In hypocotyls there seems, in general, to be a direct relationship between the overall growth response and the response of nucleic acid synthesis to treatment with these two chemicals. However, for $\mathrm{GA}$ at $10^{-6} \mathrm{M}$, a large increase in nucleic acid activity above control level did not mani- 
fest itself in a comparable growth. This is interesting in light of the fact that in a plant variety that shows accelerated growth with $G A$ it would be expected that the nucleic acid activity would be increased. Is it possible that here GA is acting on nucleic acids as $1 t$ would in a plant in which it promotes growth but some other factor is arresting the transiation of this promoted nucleic acid level into growth?

At the same time, in a plant whose hypocotyl and/or shoot erouth is promoted by GA, the GA usually retards the growth of their roots. Table 6 shows that al though GA has retarded nucleic acid activity in roots, this has not been reflected in a comparable reduction in root growth. Is 1 t possible that the "translation factor" which was not adequate in the hypocotyls was so in the roots? This could allow near normal growth from sub-normal nucleic acid production.

Alternatively, GA is well known to induce the synthesis of hydrolytic enzymes in aleurone layers of barley seeds and in other plart tissues. GA could be inducing the production of ribonucleases in hypocotyls and inhibiting their production in roots, not an uncommon mode of action for plant hormones. This could result, in hypocotyls, in an increased specific activity without an increase in growth; while in roots the specific activity would be reduced but not necessarily the growth.

The interrelation between AMO-1618, growth, and nucleic acid synthesis seems to be fairly direct in hypo- 
cotyls but in roots the AMO-1618 concentration that produces the greatest nucleic acid activity results in the least growth while $\mathrm{AMO}-1618$ at $10^{-7} \mathrm{M}$, whlch does not change nucleic acid activity relative to controls, greatiy increases growth.

When a retarding concentration of AMO-1618 $\left(10^{-4} \mathrm{M}\right)$ is combinec with various concentrations of $\mathrm{GA}\left(10^{-8}\right.$ and $\left.10^{-4}\right)$ there seems to be a fairly direct relationship between nucleic acid activity and growth. In hypocotyls GA at $10^{-8} \mathrm{M}$ plus AMO-1618 at $10^{-4} \mathrm{M}$ acts like an augmented AMO-1618 at $10^{-4} \mathrm{M}$. GA $\left(10^{-4} \mathrm{M}\right)$ pIus AMO-1618 $\left(10^{-4} \mathrm{M}\right)$ acts Iike a diminished AMO-1618 $\left(10^{-7} \mathrm{M}\right)$. A degree of competition between $\mathrm{GA}$ and $\mathrm{AMO}-1618$ can be inferred from these results. In other woras, a low GA concentretion $\left(10^{-8} \mathrm{~N}\right)$ effectively competes with the ANO-1618 to reduce the effective concentration of AMO-1618 slightly and therefore increasing nucleic acid activity and growth slightly. A high GA concentration $\left(10^{-4} \mathrm{M}_{1}\right)$ more effectively competes and reduces greatly the operative concentration of AMO-1618 and greatly increases nucleic acid activity and growth.

In roots, however, growth followed the effect of the AMO-1618 (10 $\left.0^{-4} \mathrm{M}\right)$ with either GA $\left(10^{-8} \mathrm{M}\right)$ or $\left(10^{-4} \mathrm{M}\right)$ whereas nucleic acid activity seemed to show the reducing effect of the presence of GA as though the effects of the two chemicals was not as closely related as they were in hypocotyls. 


\section{DISCUSSION}

The woris reported in this thesis shows what appears to be a novel relationship between GA and AMO-1618. Ounsworth and Pillay (1969) have shown that the srowth of shoots of light-grown soybeans is enhanced by $G A$ and retarded by Alar. When, however, dark-grown soybean seedings are treated with GA and AMO-1618 prior to the initiation of epicotyl growth, as was done in this thesis, the effect of GA on the growth Is minimal while the effect of AHO-1618 is retarding at high concentrations and very stimulatory at low concentrations. Lang (1970) cautioned that plants giving such atypical responses to retardants "are no suitable material on which to use retardants for studying GA physlology".

This work, however, shows that an investigation of such atypical responses may afford even greater insight into the physiology of plant responses to these chemicals. Lang's stricture (iden) that an interaction between GA and a retardant "can be related causally only if the effect on growth can be completely overcome by applied GA" was probably only meant to apply to an overcomine of a retardation. It is now clear that GA can overcome a promotive effect of the Erowth retardant AMO-1618 and that this effect is some-. what different in roots and hypocotyls. In roots a retarding

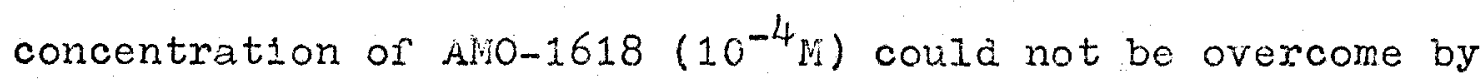
GA but a promotive concentration $\left(10^{-5} \mathrm{M}\right)$ was abolished completely even by very low GA concentrations $\left(10^{-10_{M}}\right)$. 
In hypocotyls $G A$ was able to overcome both retarding $\left(10^{-4} \mathrm{M}\right)$ and promoting $\left(10^{-5} \mathrm{M}\right)$ concentrations of AMO-1618 in a manner that implies a close interaction between them. Increasing concentrations of GA acted as though the GA was effectively reducing the concentration of AMO-1618 until high GA concentration blocked completely the promotive Alo1618 affect and the growth response became similar to the response to GA alone. It should be noted that roots could have a more finely tuned response to these chemicals and it could be that the use of fractional concentrations of Alo1618 (between $10^{-5}$ and $10^{-4}$ ) might evoke responses similar to those in hypocotyls.

The simple model of AMO-1618 action which suggests that it blocks gibberelin synthesis and thereby reduces the endogenous gibberelin level and thus retards growth cannot explain why added $G A$ does not affect appreciably the growth of soybean hypocotyls and roots, and even retards them at higher concentrations. Neither does it explain how AMO-1618 can cause a promotion of growth which can be clearly altered by GA application. It may be that more subtle effects of AMO-1618 have been masked by the masslve doses normally used to block GA synthesis completely $\left(10^{-4} \mathrm{M}\right.$ and greater). Lockhart (1962) has described kinetic studies which indicate that $\mathrm{CCC}$ and phosphon interact competitively with gibberelin on stem growth of light-grown pinto beans but not on root growth. He indicates that, al though InneweaverBurk analysis is not possible because $11 \mathrm{ving}$ systems cannot 
be made free of endogenous growth iactor, simple dose-response curves can supply considerable information. He says that "whenever a growth factor can completely eliminate the influence of a second factor in a properly controlled system, a competitive interaction is demonstrated."

The type of interaction exhibited in hypocotyls between $\mathrm{GA}$ and $\mathrm{AHO}-1618$ at $10^{-4} \mathrm{M}$ represents what would be expected if an allosteric enzyme were involved, where AMO-1618 is acting as the substrate and $G A$ is acting as the competitive inhibitor. If this is the case then some allosteric enzyme like aspartate transcarbamylase which controls pyrimidine biosynthesis in $\mathrm{E}$. coli could be worth investigation. The effect of AMO-1618 and GA on nucleotide pools might afford preliminary evidence of the involvement of such an enzyme. This 1 s suggested by the work of Johri and Varner (1968) who found that nearest-neighbor analysis of PNA synthesized by GA-exposed pea nuclei showed a higher frequency of adenineand guanine-containing pairs and a lower frequency of cytosine- and uracil-containing pairs. The attractiveness of this possibility is enhanced by the fact that Aro-1618, like the normal substrate for aspartate trenscarbamylase, is a carbamate. 


\section{SUPMARY}

A simplified, three-layered MAK column has been found to satisfactorily separate soybean mucleic acid extracts into their typical fractions. In adition the direct counting of aqueous solutions of 32 Pi-labelled nucleic acid f'ractions by the Cerenkov counting procedure of Haviland and Bieber (1970) has been found to give satisfactory, repeatable results.

Significant incorporation of 32 pi into nucleic acid fractions from NAK columns begins 24 to 48 hours after imbibition starts. Roots appear to incorporate $32 \mathrm{Pi}$ into nucleic acids much more erficiently than do hypocotyls or cotyledons.

H1gh concentrations of AMO-1618 (10-4 and higher) progressively reduce ${ }^{32} \mathrm{Pi}$ incorporation in imbibing seeds and in 6 day old hypocotyls, but augment incorporation into roots. GA has Iittle effect on incorporation by roots but seems to progressively reduce ${ }^{32} \mathrm{Pl}$ incorporation into hypocotyl nuclejc acids. GA could not overcome the reduction in Incorporation by a high concentration of AMO-1618 in roots but hypocotyls grown in a combination of GA and AMO-1618 showed a ${ }^{32}$ pi incorporation comparable to that obtained with a reduced AMo-1618 concentration alone. Allo-1618 promoted the growth in length of both roots and hypocotyls at concentrations $10^{-5} \mathrm{M}$ or lower, while higher concentrations significantly retarded both. GA is capabie of overcoming the growth effect of a promotive 
concentration of AMO-1618 in both parts of the piant; however, whereas it could not overcome an inh1bitory AMO-1618 concentration in roots, it could in hypocotyls in a manner suggestive of the interaction of substrate and inhibitor on an allosteric enzyme. It is suefested that studies of an enzyme like aspartate transcarbamylase and of nucleotide pools in this system may prove frultful. 


\section{Appendix}

(Essentially as outlined by Usawa and Sibatani)

I Washing the Kieselguhr

1. Suspend $150 \mathrm{~g}$ Kieselguhr in $600 \mathrm{~m} 1$ of $1 \mathrm{~N} \mathrm{NaOH}$ overnight.

2. Filter on Buchner funnel and wash with $450 \mathrm{~mL}$ of

1. $\mathrm{N} \mathrm{NaOH}$.

3. Suspend in $300 \mathrm{~mL}$ of $\perp \mathrm{N}$ HCI overnignt.

4. Hilter and wash with $450 \mathrm{ml}$ of $\mathrm{l} \mathrm{N} \mathrm{HCl}$.

5. Wash with distilled water until no Longer acid

(approx. $1000 \mathrm{ml}$ )

o. Suspend in distilled water.

7. Decant to remove fine particles--repeat once.

\section{Methylating the Albumin}

(Essentially by the procedure of Mandell and Hershey)

1. Suspend $5 \mathrm{gm}$ of bovine serum albumin (fraction $v$ ) in $500 \mathrm{ml}$ of fireshly opened absolute methanol.

2. Add $4.2 \mathrm{~mL}$ of concentrated HCI slowly with stirring.

3. Tigntly seal and incubate in the dark at $37^{\circ} \mathrm{C}$ for 5 days. Shake olten.

4. Quickly cool and centrituge at $20,000 \mathrm{x} g$ for $10 \mathrm{~min}$.

5. Wash twice, or until yellow colour is gone, with cold methyl alcohol.

6. Wash twice with cold, newly opened, anhydrous ether.

7. Pour off supernatant and air dry residue while working it with a spatula to reduce it to a powder. 
8. Store in vacuo over $\mathrm{KOH}$.

NOTE For each new supply of methylated albumin a new salt gradient range must be established. This can be done by eluting a nucleic acid sample through the new MAK using a wide salt gradient (ex. 0.2M--2.OM). Froin the resulting profile a new, suitable gradient range can be determined.

\section{Preparation of Bentonite}

(Essentially the method H. Fraenkel-Conrat et al, 1961)

1. Stir $10 \mathrm{~g}$ Bentonite in $200 \mathrm{ml}$ of distilled water for I hour.

2. Centrifuge at $2500 \mathrm{rpm}$ tor 15 minutes.

3. Recentrifuge supernatant at 8500 rpm for 20 minutes.

4. Resuspend residue in 0.1 M Versene, $\mathrm{pH} 7$, for $48 \mathrm{hrs}$. . at $25^{\circ} \mathrm{C}$.

5. Centrifuge at $2.500 \mathrm{rpm}$ for 15 minutes.

6. Centrifuge supernatant at $\$ 500$ rpm for 20 minutes.

7. Suspend residue in $0.01 \mathrm{~m}$ acetate buffer, $\mathrm{pH} 6$.

8. Centrituge at $8500 \mathrm{rpm}$.

9. Freeze-dry.

10. Make $40 \mathrm{mg} / \mathrm{ml}$ with $0.1 \mathrm{M}$ acetate buffer, $\mathrm{pH} 5.0$ 
IV Preparing the Column

Beaker I

$1 \mathrm{~g}$ paper powder in $20 \mathrm{ml} 0.1 \mathrm{M}$ buffered saline
Beaker II

$10 \mathrm{~g}$ Kieselguhr in $50 \mathrm{ml}$ of $0.1 M$ buffered saline

Boil ( 1 min) Cool

Add $2.5 \mathrm{ml}$ (siow \& stir)

$1 \%$ Methylated

albumin
Add to closed column (use inverted $10 \mathrm{ml}$ pipette)
Drip to pack then close

Carefully wash with $0.1 \mathrm{MI}$

\section{Gently layer on to paper}
Drip to pack using pressure $(2-3$ psi)
Wash with $200 \mathrm{ml}$ of $0.1 \mathrm{M}$ using pressure

Beaker III

$1 \mathrm{~g}$ Kieselguhr in $10 \mathrm{ml}$ of O.I M buffered saline

Boil (1 min) Cool

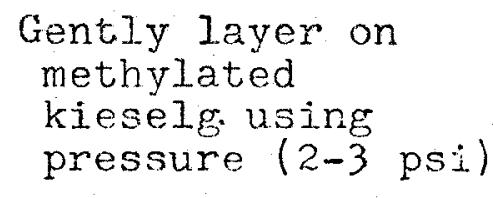

Drip to $1 \mathrm{~cm}$ of paper

\section{$V$ Loading the Column}

1. Dissolve $350.0{ }^{\prime} \mathrm{s}(1.75 \mathrm{mg})$ in $40 \mathrm{mI}$ of starting buffer.

2. Add to column at a rate of $1 \mathrm{ml} / \mathrm{min}$. with pressure (2-3 psi)

3. Wash with $20 \mathrm{ml}$ of starting buffer.

4. Wash with $10 \mathrm{~m} 1$ of starting buffer.

5. Stop $1-2 \mathrm{~cm}$ from top. 
Baldev, B., Lang, A., and Agatep, A.0. 1965. Givberelin production in pea seeds developing in excised pocis: Effect of growth retardant AMO-1618. Science. 147, $155-57$.

Bardense, G.W.M., Kende, H., and Lang, H. 1968. Fate of radioactive gibbereliln $\mathrm{A}_{1}$ in maturing and germinating seeds of peas and Japanese morning flory. plant Fhysiol. 43, $815-822$.

Cathey, H. M. 1965. plant selectivity in response to variation in the structure of Allo-1618. Fhyton. 22, 19-26

Cherry, J.H. and Chroboczek, H. 1966. Factors affecting nucleic acid extractability in plants. Fhytochemistry. 5, 411-122.

Dennis, D.T., Upper, C.D., and West, C.A. 1965. An enzymic site of inhibition of gibberelin biosynthesis by AMO1618 and other plant growth retardants. Flant Physiol. 40, $948-52$.

Gayler, K.R. end Glasziov, K.T. 1969. Plant enzyne synthesis: hornonal resulation of invertase and peroxidase synthesis in sugar cane. Planta. 84, 185-94.

Holevy, A. E. 1963. Effects of gibberelin and growthretardins chemlcals on respiration and catalase activity in various organs of cucuraber seedings. I. Exp. Bot. 15, 546-55.

Halevy, A.H. and Cathey, H.M. 1960a. Erfect of concentration and structure of eibberelins on erowth of cucumber (Cucumis sativus) seedlines. Bot. Gaz. 122, 63-67.

Halevy, A.H. and Cathey, H.M. 1960b. Effect of structure and concentration of sorie quaternary ammoniur compounds on growth of cucumber seedi1ngs. Bot. Gaz. 122, 151-54.

Haviland, R. T. and Bleber, I.L. 1970. Scintiliation countins of $32 \mathrm{p}$ without added scintiliator in aqueous solutions and organic solvents and on dry chromatographic media. Anal. Biochem. 33, 323-34.

Johri, M.M. and Varner, J.E. 1968. Enhancement of RNA synthesis in 1 solated pea nuclet by gibberellic acid. Proc. Nat. Acad. Sc1. USA. 59, 269-76. 
Johri, M.M. and Varner, J.E. 1970. Characterization of rapldty labeled riborucleje actds from dwarf peas. plant Physiol. 45, 348-358.

Jones, R.L. and Fhillips, I.D.J. 1966. Organs of gibberelin synthesis in 1 isht-grown sunflower plants. Plant Physiol. $41,1381-86$.

Kende, H. and Lang, A. 1964. Gibberelilns and light inhibition of stem srowth in peas. Flant Physiol. 39, $435-440$.

Lang, A. 1970. Gibberellins: structure and netabolism. Ann. Rev. Plant Physiol. 21, 537-570.

Lockhart, J.A. 1962. Kinetic studies of certain antigibberelinins. Plant Phys10l. 37, 759-64.

Mande1I, J.D. and Hershey, A. D. 1960. A fractionating colum for arialysis of nucleic acids. Anal. Biochem. $1,66-77$.

Matthysse, A.G. and Fhillips, C. 1969. A protein intermediary in the interaction of a hormone with the genome. Proc. Nat. Acad. Sc1. USA. 63, 897-903.

Osava, S. and Sibatani, A. 1967. Chromatographic separation of RNA froin DNA on MAK columns. In Methods of Enzymology: Nucleic acids, Part A, Vol. KII" (I. Grossman and $K$. Moldane, eds.), Academic Fress, New York.

Ounsworth, L.F. and Pillay, D.T.N. 1969.: Responses of soybeans to gibberellic acid and succinic acid 2,2dimethyl hydrazide (Alar) at different levels of nitrogen, phosphorus, and potassium. Phyton. 26. $20.7-12$.

Paleg, I.G. 1960a. Physiological effects of gibberelic acid: I. on carbohydrate metabolism and amylase activity of barley encosperm. Plant Fhysiol. 32, 293-99.

Paleg, L.G. 1960b. Physiological effects of giboerellic acid: II. on starch hydrolyzins enzymes of barley endosperm. Plant Ehys10.2. 35, 902-6.

Paleg, I.G. 1965. Ehysiological effects of cibberellins. Ann. Rev. Plant Physiol. 16, 291-322.

Radiey, 1970. Comparison of endogenous gibbereli1ns and. response to applied gibbereli in of some dwarf and tall wheat cultivars. Planta $22,292-300$. 
Tamura, S., Takahashi, N., Katsumi, M., Phinney, B.D., and Kato, J. 1969. "GibbereIIins: Blochemistry and

Fhysiology", Univ. Tokyo Press, 372pp.

Warner, A.H. and $M^{C}$ Clean, D.K. 1968. Studies on the biosynthesis and role of diguanosive tetra phosphate during growth and development of Artemia salina. Dev. Biol. 18, 278-293.

Wirwille, J.W. and Mitchell, J.W. 1950. Six new plantgrowth-inhibiting compounds. Bot. Gaz. 111, 491-94.

Yasuda, T. and Yamada, Y. 1970. Complex formation by 2, 4dichlorophenoxyacetic acid with histones during callus induction. Biochem. and Biophys. Res. Comm. 40,

Yomo, H. 1958. (In Japanese). Hakko Kyokai Shi. 16, 444-48. 1960. 1bid. 18, 494-99, $\overline{500-2}, \frac{600-2}{603-5 .}$ 
VITA AUCTORIS

Born:

February 27, 1932. Windsor, Ontario.

Son of Mr. and Mrs. Peter Soteros

Elementary Education:

Windsor, ontario.

Secondary Education:

Hon. W.C. Kennedy Colleglate Institute, Windsor, ontario $1945-1951$.

Unlversity Education:

Assumption College, Windsor, Ontario, 1951-1954.

B.Sc. in Biology.

Ontario College of Education, Toronto, ontario. $1954-1955$.

Married:

March 31,1956 to Wargaret Biggar, Windsox, ontario. Parents or Robert, Christine, David, and Kathryn.

Teaching Experience:

Essex District ligh school, Essex, Ontario, 1955-1960.

Vincent Wassey Secondary School, Winasor, Ontario, $1960 \ldots .$. 
